\title{
Improvement of grapevine physiology and yield under summer stress by kaolin-foliar application: water relations, photosynthesis and oxidative damage
}

\author{
L.-T. DINIS*,+, A.C. MALHEIRO*, A. LUZIO*, H. FRAGA*, H. FERREIRA*, I. GONÇALVES ${ }^{* *}$, \\ G. PINTO ${ }^{* * *}$, C.M. CORREIA*, and J. MOUTINHO-PEREIRA* \\ Centre for the Research and Technology of Agro-Environmental and Biological Sciences (CITAB), \\ Universidade de Trás-os-Montes e Alto Douro, Apt. 1013, 5001-801 Vila Real, Portugal ${ }^{*}$ \\ Associação para o Desenvolvimento da Viticultura Duriense (ADVID), Edificio Centro de Excelência da Vinha \\ e do Vinho, Parque de Ciência e Tecnologia de Vila Real - Régia Douro Park, 5000-033 Vila Real, Portugal* \\ Department of Biology \& CESAM - Centre for Environmental and Marine Studies, \\ Universidade de Aveiro, Campus Universitário de Santiago, 3810-193 Aveiro, Portugal ${ }^{* * *}$
}

\begin{abstract}
Knowledge about short-term climate change adaptation strategies for Mediterranean vineyards is needed in order to improve grapevine physiology and yield-quality attributes. We investigated effects of kaolin-particle film suspension on water relations, photosynthesis and oxidative stress of field-grown grapevines in the Douro region (northern Portugal) in 2012 and 2013. Kaolin suspension decreased leaf temperature by $18 \%$ and increased leaf water potential (up to $40.7 \%$ in 2013). Maximum photochemical quantum efficiency of PSII was higher and the minimal chlorophyll fluorescence was lower in the plants sprayed by kaolin. Two months after application, net photosynthesis and stomatal conductance at midday increased by 58.7 and $28.4 \%$, respectively, in treated plants. In the same period, kaolin treatment increased photochemical reflectance, photosynthetic pigments, soluble proteins, soluble sugars, and starch concentrations, while decreased total phenols and thiobarbituric acid-reactive substances. Kaolin application can be an operational tool to alleviate summer stresses, which ameliorates grapevine physiology and consequently leads to a higher yield.
\end{abstract}

Additional key words: biochemistry; Douro region; oxidative stress; Vitis vinifera.

\section{Introduction}

Europe presents the largest vineyard area in the world (about 38\%), that is located under Mediterranean climate and is characterized by long growing seasons, mild to warm temperatures, and dry summers (Fraga et al. 2016). In the last years, much attention has been focused on climate change and its impact on viticulture (Jones et al. 2005, Hannah et al. 2013, Fraga et al. 2014a). For these Mediterranean-like climatic regions, future projections point to an increased warming and drying, which is expected to result in lower water availability (IPCC 2013).

Received 7 October 2016, accepted 20 December 2016, published as online-first 13 March 2017.

${ }^{+}$Corresponding author; e-mail: liatdinis@utad.pt

Abbreviations: $\mathrm{Chl}$ - chlorophyll; $\mathrm{Car}$ - carotenoid; $C_{\mathrm{i}} / C_{\mathrm{a}}-$ internal $\mathrm{CO}_{2}$ concentration/ambient $\mathrm{CO}_{2}$ ratio; $E$ - transpiration rate; ETR - photosynthetic electron transport rate; $F_{0}$ - minimal chlorophyll fluorescence; $F_{v}$ - variable chlorophyll fluorescence; $F_{m}-$ maximal chlorophyll fluorescence; $\mathrm{F}_{\mathrm{v}} / \mathrm{F}_{\mathrm{m}}$ - maximum photochemical quantum efficiency of PSII; $\mathrm{F}_{\mathrm{v}}$ ' $/ \mathrm{F}_{\mathrm{m}}{ }^{\prime}$ - capture efficiency of excitation energy by open PSII reaction centres; $g_{\mathrm{s}}-$ stomatal conductance; $P_{\mathrm{N}}-$ net $\mathrm{CO}_{2}$ assimilation rate; $\mathrm{q}_{\mathrm{N}}$ - nonphotochemical quenching; qP photochemical quenching; RIred edge - chlorophyll reflectance index; SP - soluble proteins; SS - soluble sugars; St - starch; TBARS thiobarbituric acid-reactive substances; TP - total phenols; $\Phi_{\text {PSII }}$ - actual PSII efficiency; $\Psi_{\mathrm{md}}$ - midday leaf water potential; $\Psi_{\mathrm{pd}}-$ predawn leaf water potential, $\mathrm{WUE}_{\mathrm{i}}-P_{\mathrm{N}} / g_{\mathrm{s}}$, intrinsic water-use efficiency.

Acknowledgements: The study was undertaken under the IC\&DT INTERACT project - "Integrated Research in Environment, AgroChain and Technology", no. NORTE-01-0145-FEDER-000017, in its line of research entitled VitalityWINE, co-financed by the European Regional Development Fund (ERDF) through NORTE 2020 and Award "Fundação Maria Rosa" to our team. The postdoctoral fellowships awarded to L.-T. Dinis (SFRH/BPD/84676/2012), A. Luzio (BPD/INTERACT/VITALITYWINE/184/2016), and G. Pinto (SFR/BPD/101669/2014) are appreciated. We would also like to thank to "Quinta do Vallado" for the collaboration and efforts in making the vineyard's facilities available for the research and particularly to António Pinto and Daniel Gomes and BASF for collaboration. 
This combined effect, including longer periods of high air temperatures followed by high evaporative demands and drought, could result in damaging effects during the grapevine growing season, not only on a yield but also on grape and wine quality (Chaves et al. 2007, Fraga et al. 2014 b). Wine-making regions, which are already on the limits of $V$. vinifera L. climatic suitability, could face further threats in order to preserve high quality wine production (Jones et al. 2005, Fraga et al. 2013). Furthermore, traditionally cultivated grapevine varieties, which are used in the production of renowned high quality wines, may experience additional stresses, which may challenge wine typicity (Ferrandino and Lovisolo 2014). It is known that the occurrence of these stresses may promote dramatic decrease in plant carbon assimilation as the result of severe decay of net photosynthesis, as well as a partial loss of canopy leaf area (Chaves et al. 2007, dos Santos et al. 2007, Moutinho-Pereira et al. 2004). The high temperature conditions also affect numerous physiological processes, including modifications in photosynthesis efficiency (Moutinho-Pereira et al. 2007), transport and accumulation of assimilates (Sampol et al. 2003), respiration and mineral nutrition. The photosynthetic limitation decreases sugar synthesis, leading to reduction not only of the yield, but also of the fruit quality (dos Santos et al. 2007). Additionally, an increase in total polyphenols is induced under such stressful conditions (Moutinho-Pereira et al. 2007, Wen et al. 2008).

\section{Materials and methods}

Plant material, growth conditions and treatments: The trial was carried out in 2012 and 2013 in "Quinta do Vallado", a commercial vineyard of Douro Demarcated Region (Denominations of Origin Douro and Porto)

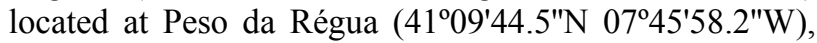
northern Portugal. The climate is typically Mediterranean, with high precipitation during the winter months and dry and hot in the summer (Kottek et al. 2006). An automatic weather station recorded rainfall, mean air temperature, and solar radiation during the trial period. According to the World Reference Base for Soil Resources 2014 (FAO 2015), the soil mapping of the region is classified as dystric technosols taking into account their acidity and deep modification by human actions. The rainfed plants were managed under commercial viticultural practices. In order to study the potential of kaolin application, the Portuguese Touriga nacional variety (Vitis vinifera L.), grafted onto $110 \mathrm{R}$ rootstock, was selected. In a steep hill with an N-S row orientation, 6-year-old vines were trained to unilateral cordon and the spurs were pruned to two nodes each with 10-12 nodes per vine. Three vineyard rows, with twenty plants each, were sprayed soon after veraison (11 July in 2012 and 17 July in 2013) with 5\% (w/v) kaolin (Surround WP, Engelhard Corp., Iselin, New Jersey). A second application on the same days was performed to ensure kaolin adhesion uniformity. Other three vineyard rows,
As irrigation becomes economically unsustainable in the Douro region, special attention must be focused on minimizing these adverse effects. Foliar sprays with inert reflective materials, such as kaolinite clay $\left[\mathrm{Al}_{2} \mathrm{Si}_{2} \mathrm{O}_{5}(\mathrm{OH})_{4}\right]$, have been used in greenhouses and orchard systems in order to increase light reflectance and to reduce canopy temperature (Shellie and King 2013) and water stress. The kaolin particles has been provided to reflect potentially damaging ultraviolet and infrared radiation, as well as to allow the transmission of photosynthetically active radiation (Glenn and Puterka 2005), to reduce leaf temperature (Shellie and King 2013) and sunburns, and to increase leaf carbon assimilation (Glenn et al. 2001). In the same experiment during three years, we found that kaolin interferes with some parameters that are related to the PSII photochemical performance (Dinis et al. 2016a) and fruit quality (Dinis et al. 2016b). In this work, with the purpose of complementing information, we presented their effects on spectral leaf reflectance, leaf temperature, water status, carbon metabolism, oxidative stress indicators, and yield. In this context, the aim of this study was to i) evaluate the efficiency of foliar-sprayed kaolin in canopy cooling and in mitigation of damages associated with excessive sun leaf exposure, ii) and to determine how this exposure influences water relations, photosynthesis, and yield in grapevines under a typical Mediterranean-like climate.

side-by-side (for ensuring similar edaphoclimatic conditions between treatments), with twenty plants each, were used as control, i.e. without kaolin application. The control plants were carefully protected by a plastic film during the kaolin application. In 2012, an additional kaolin application was done (30 July), to compensate for the partial kaolin removal due to a high precipitation event.

The supplementary data (Fig. 1S, supplement available online) shows monthly total values of rainfall (Rf, April to October), solar radiation, and air temperature from May to October in 2012 and 2013. The Rf values were higher in 2012 than that in 2013, except of those in October. Relating to temperature, values were significantly higher in 2013, except those in May. Light incident was also higher in 2013, except in May and June. Thus, 2013 was warmer and drier than 2012.

Reflectance: By using the same leaf samples to measure the gas exchange and chlorophyll (Chl) $a$ fluorescence, the spectral reflectance was determined following the procedures described in Moutinho-Pereira et al. (2012). Briefly, ten scans per sample were integrated (integration time of $10 \mathrm{~ms}$ ) and a total of three measurements were acquired within the marked homogeneous area of each leaf. Then the average of these measurements was calculated to establish a single representative reflectance 
spectrum per leaf and from this, several reflectance indices were computed for measuring the changes between leaves with and without the kaolin treatment. Chl reflectance index $\left[\mathrm{RI}_{\text {red edge }}\right]$ was calculated as $\left[\left(\mathrm{R}_{750-800}\right) /\left(\mathrm{R}_{695-740}\right)\right]-1$ (index with broad spectral band and positively correlated with Chl content) (Gitelson and Merzlyak 2004).

Leaf temperature was measured with an infrared thermometer (Infratrace KM800S, England) with a $15^{\circ}$ field view, throughout veraison (late July) and ripening stage (August and early September). Measurements were performed under clear sunny days and on sun-exposed and fully expanded leaves at the middle of the shoots (usually between $8^{\text {th }}$ and $11^{\text {st }}$ nodes on the shoot axes). The average temperature of two randomly selected leaves (in eight plants) in each plot was obtained by holding the thermometer at about $1 \mathrm{~m}$ above the foliar surface.

Water relations: The volumetric water content of the soil was monitored by time-domain reflectometry using a MiniTrase (SoilMoisture, USA) at approximately 20-30 d intervals over the growing seasons. For this purpose, in each treatment, six replicates of $0.6 \mathrm{~m}$ heavy-duty wave guides were inserted in the vine row, at $0.30 \mathrm{~m}$ apart from the trunk. At a given date, the fraction of available soil water was computed as the difference between the soil water content on the day of measurements and the minimum soil water content, and that was divided by the total available water in the defined soil profile $(0-0.6 \mathrm{~m})$.

Leaf water potential $(\Psi)$ was determined according to Dinis et al. (2014). Briefly, $\Psi$ was determined with a pressure chamber (Model 1000, PMS Instrument Company, Albany, USA) at pre-veraison (July), veraison (August), and the maturation (early September) stage. Measurements were performed on eight fully expanded leaves at predawn (6:00 h, $\left.\Psi_{\mathrm{pd}}\right)$ and midday (13:00-14:00 h, $\left.\Psi_{\mathrm{md}}\right)$.

Leaf gas exchange was measured with an infrared gas analyser (LC Pro+, ADC Bioscientific Ltd., UK), operating in the open mode. Measurements were carried out in the morning (09:00-10:30 h) and midday (14:00-15:30 h) period on 31 July and on 4 September (maturation) in 2012, and on 11 September in 2013. In 2013, only one day of measurements (September) was performed due to infrared gas analyser failure in previous months. Net $\mathrm{CO}_{2}$ assimilation rate $\left(P_{\mathrm{N}}\right)$, stomatal conductance $\left(g_{\mathrm{s}}\right)$, transpiration rate $(E)$, and internal $\mathrm{CO}_{2}$ concentration/ambient $\mathrm{CO}_{2}$ ratio $\left(C_{\mathrm{i}} / C_{\mathrm{a}}\right)$ were estimated according to von Caemmerer and Farquhar (1981). To eliminate the possible effects of air humidity and temperature on transpiration, the $P_{\mathrm{N}} / g_{\mathrm{s}}$ ratio, rather than the $P_{\mathrm{N}} / E$ ratio, was calculated in order to evaluate the intrinsic water-use efficiency (WUE $)_{\mathrm{i}}$ (Iacono et al. 1998).

Chl $\boldsymbol{a}$ fluorescence was obtained in situ at the same periods of gas-exchange measurements by using a pulseamplitude-modulated fluorimeter (FMS 2, Hansatech
Instruments, Norfolk, England). Maximum quantum efficiency of PSII was calculated as $\mathrm{F}_{\mathrm{v}} / \mathrm{F}_{\mathrm{m}}=\left(\mathrm{F}_{\mathrm{m}}-\mathrm{F}_{0}\right) / \mathrm{F}_{\mathrm{m}}$, by measuring the fluorescence signal from 30-min darkadapted leaves, when all reaction centres are open, using a low intensity pulsed measuring light source $\left(\mathrm{F}_{0}\right)$, and during a pulse saturating light $[0.7 \mathrm{~s}$ pulse of 15,000 $\mu$ mol(photon) $\mathrm{m}^{-2} \mathrm{~s}^{-1}$ of white light], when all reactions centres are closed $\left(\mathrm{F}_{\mathrm{m}}\right)$. Following $\mathrm{F}_{\mathrm{v}} / \mathrm{F}_{\mathrm{m}}$ estimation, after a 20 -s exposure to actinic light $\left[1,500 \mu \mathrm{mol}\right.$ (photon) $\left.\mathrm{m}^{-2} \mathrm{~s}^{-1}\right]$, light-adapted steady-state fluorescence yield $\left(\mathrm{F}_{\mathrm{s}}\right)$ was averaged over $2.5 \mathrm{~s}$, followed by exposure to saturating light $\left[15,000 \mu \mathrm{mol}\right.$ (photon) $\left.\mathrm{m}^{-2} \mathrm{~s}^{-1}\right]$ for $0.7 \mathrm{~s}$ to establish $\mathrm{F}_{\mathrm{m}}$ '. The sample was then shaded for $5 \mathrm{~s}$ with a far-red light source to determine $\mathrm{F}_{0}$ '. From these measurements, several fluorescence attributes were calculated (Bilger 1986 , Genty et al. 1989) as the photochemical quenching $\left[\mathrm{q}_{\mathrm{P}}=\right.$ $\left.\left(\mathrm{F}_{\mathrm{m}}{ }^{\prime}-\mathrm{F}_{\mathrm{s}}\right) /\left(\mathrm{F}_{\mathrm{m}}{ }^{\prime}-\mathrm{F}_{0}{ }^{\prime}\right)\right]$, nonphotochemical quenching $\left(\mathrm{q}_{\mathrm{N}}=\right.$ $1-\left(\mathrm{F}_{\mathrm{v}}{ }^{\prime} / \mathrm{F}_{\mathrm{v}}\right)$, and efficiency of electron transport evaluated as $\Phi_{\text {PSII }}\left[\Phi_{\text {PSII }}=\Delta \mathrm{F} / \mathrm{F}_{\mathrm{m}}{ }^{\prime}=\left(\mathrm{F}_{\mathrm{m}}{ }^{\prime}-\mathrm{F}_{\mathrm{s}}\right) / \mathrm{F}_{\mathrm{m}}{ }^{\prime}\right]$. The photosynthetic electron transport rate (Marinari 2007) was estimated as $\mathrm{ETR}=\left(\Delta \mathrm{F} / \mathrm{F}_{\mathrm{m}}{ }^{\prime}\right) \times \mathrm{PPFD} \times 0.5 \times 0.84$, where PPFD is the photosynthetic photon flux density incident on the leaf, 0.5 is the factor that assumes equal distribution of energy between the two photosystems, and the leaf absorbance used was 0.84 because is the most common value for $\mathrm{C}_{3}$ plants (Bilger 1986).

Foliar pigments, metabolites and oxidative stress indicators: The assays were analysed in the same leaves used for gas exchange and Chl $a$ fluorescence measurements at two different stages (July and September in 2012 and 2013). They were treated according to Dinis et al. (2014). Leaf sections were ground in $80 \%$ acetone for $\mathrm{Chl}$ and carotenoid (Car) determination. $\mathrm{Chl} a, \mathrm{Chl} b$, total $\mathrm{Chl}$ $(a+b)$, the Chl $a / b$ ratio (Šesták et al. 1971), and total Car (Lichtenthaler 1987) were determined in UV/Vis VARIAN spectrophotometer (CARY 100 Bio, Australia). The total phenols (TP) in leaf extracts were determined according to the Folin-Ciocalteu's procedure (Singleton and Rossi 1965) on the same extract used for pigment analysis.

Soluble sugars (SS) were extracted by heating leaf discs in $80 \%$ ethanol and quantified according to the method of Irigoyen et al. (1992). The absorbance at $625 \mathrm{~nm}$ was determined in UV/Vis VARIAN spectrophotometer (CARY 100 Bio, Australia). Starch (St) was extracted with 30\% perchloric acid (Osaki et al. 1991) and its concentration was determined by the anthrone method. Glucose was used as standard for both soluble sugars and starch. The total soluble proteins (SP) were extracted using an extraction buffer containing phosphate of $\mathrm{pH} 7.5$ with ethylenediaminetetraacetic acid (EDTA) and quantified according to the method of Bradford (1976). The lipid peroxidation products in grape leaves were estimated as discribed by Heath and Packer (1968), with measurements of the supernatant at 532 and $600 \mathrm{~nm}$ in UV/Vis VARIAN spectrophotometer (CARY 100 Bio, Australia). The extration were done with $3 \mathrm{ml}$ of $20 \%$ (w/v) trichloroacetic 
acid (Rosati et al. 2006) and total thiobarbituric acidreactive substances (TBARS) was quantified using an extinction coefficient of $157 \mathrm{M}^{-1} \mathrm{~cm}^{-1}$ (Costa et al. 2002).

Yield: Total fruit mass was determined in each plant using a hand held balance ( $n=60$ plants per treatment).

Statistics: Statistical analyses were performed with Sigma-Plot 12.0 program (SPSS Inc.). After testing for

\section{Results}

Reflectance: The kaolin application resulted in significant increases in the blue and green light (400-630 nm) reflectance, and in the near infrared $(750-1000 \mathrm{~nm})$ wavelength regions compared with the control (Fig. 2S, supplement available online). Relatively to $\mathrm{RI}_{\text {red edge, no }}$ significant differences were observed in July 2012, whereas two months after kaolin application this index was significantly higher in the treated plants than that in control ones (Fig. 1). In 2013, the $\mathrm{RI}_{\text {red edge }}$ values were significantly higher than those obtained in 2012.

Leaf temperature values were higher in the control plants, while no significant differences were observed in both day periods in August and September 2012 (Fig. 2). Major differences between treatments were found in July in the morning (18.2 and $17.7 \%$ in 2012 and 2013, respectively), in July in midday (11.4 and $12.1 \%$ in 2012 and 2013, respectively), and in September 2013 (13.3\%). The major differences between years were observed in the midday period.

Water relations: The $\Psi_{\mathrm{pd}}$ of the kaolin-sprayed plants was higher in July, mainly in 2013 (40.7\%), whereas the $\Psi_{\mathrm{md}}$ of these plants were higher in July and also in September (6.55 and $17.9 \%$, respectively) (Table 1). Meanwhile, $\Psi_{\mathrm{pd}}$ and $\Psi_{\mathrm{md}}$ values were also dependent on the year, with higher $\Psi_{\text {pd }}$ in 2013 (July and September). These differences were not associated with available soil water because this fraction at the $0-0.6 \mathrm{~m}$ soil profile showed a similar decreasing pattern in the kaolin-treated and control plots during both years. Further, no significant differences were found between treatments, though that fraction was generally lower in 2012 due to a drier winter.

Gas-exchange parameters showed that the treated plants exhibited significantly higher values of $P_{\mathrm{N}}(31.8 \%$ higher $)$ in July 2012, only in the midday period (Table 2). Regarding to September, independently of the year, the kaolin-treated plants presented significantly higher values of $g_{\mathrm{s}}$ and $P_{\mathrm{N}}$ in both periods. However, in 2013, significant differences were also obtained in $C_{\mathrm{i}} / C_{\mathrm{a}}, P_{\mathrm{N}} / g_{\mathrm{s}}$, and $E$ in both morning and midday periods. The kaolin-treated plants showed higher $P_{\mathrm{N}} / g_{\mathrm{s}}$ and $E$, contrary to lower values of $C_{\mathrm{i}} / C_{\mathrm{a}}$. In most cases, the treatment effect was highly analysis of variance ( $A N O V A)$ assumptions (homogeneity of variances with the Levene's mean test, and normality with the Kolmogorov-Smirnov's test), statistical differences between years and treatments were evaluated by two-way factorial ANOVA, followed by the post hoc Tukey's test. In the specific case of gas-exchange parameters data were submitted to one-way factorial ANOVA. Significant differences were considered for $p<0.05$.

significant and accounted for most of the total variation than that of the year effect.

Chl $\boldsymbol{a}$ fluorescence: Relating to $\mathrm{F}_{0}$, in the morning period, all values were lower in the treated plants, except in July 2013 (Table 3). Only obtained differences were found in the $F_{m}$ values during the midday period, when the treated plants showed the higher values. The maximum quantum efficiency of PSII, estimated by the $F_{v} / F_{m}$ ratio, was generally higher in the kaolin-treated plants compared with the control plants. Concerning of $\Phi_{\mathrm{PSII}}$, there was no significant difference between treatments, but in July 2012 during the midday period. In both periods and years, the

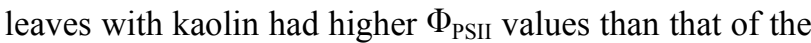
leaves without the clay particles. The qp values seemed to be affected by the year (different conditions) rather

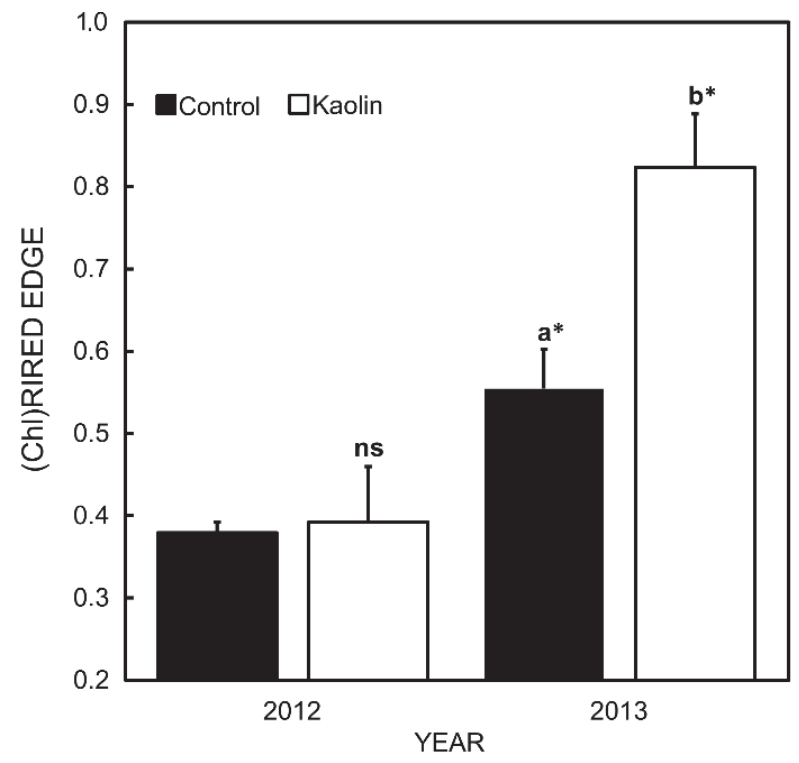

Fig. 1. Chlorophyll reflectance index (ChlRI $\mathrm{I}_{\text {red edge }}$ ) of grapevine leaves in September of 2012 and 2013. Values are presented as mean \pm standard deviation (SD), $n=8$ per treatment. Statistical analysis was performed using a two-way factorial ANOVA. Different lowercase letters represent significant differences between the treatment (control vs. kaolin), in the same year. * - significant differences between years within the same treatment $(p<0.05)$. 


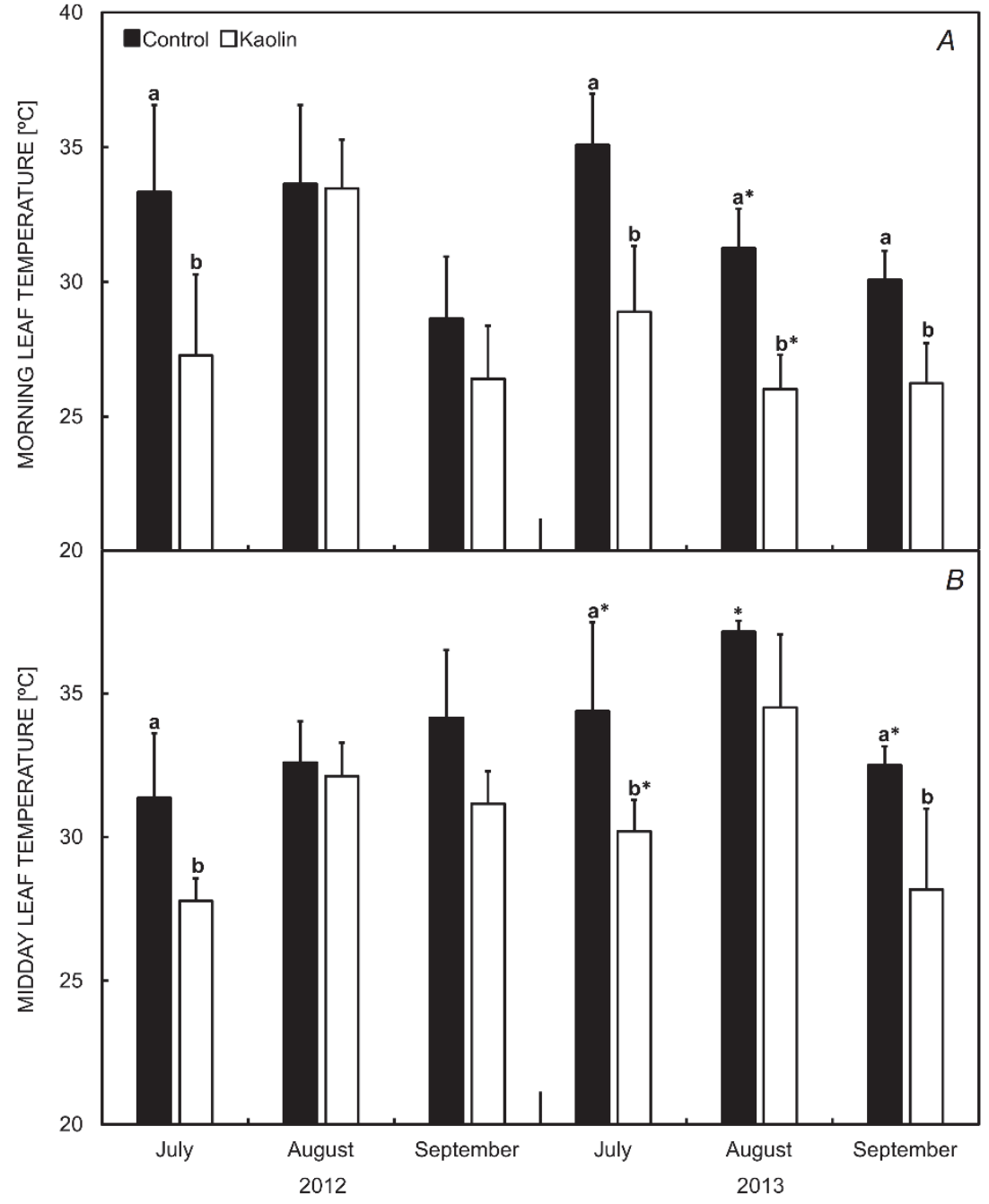

Fig. 2. Leaf temperature of kaolin-sprayed leaves and control ones measured in the morning and midday periods in July, August and September 2012 and 2013. Values are presented as mean \pm standard deviation (SD), $n=8$ per treatment. Statistical analysis was performed using a two-way factorial ANOVA. Different lowercase letters represent significant differences between the treatment (control vs. kaolin), in the same year, and * represents significant differences between years within the same treatment $(p<0.05)$.

Table 1. Predawn $\left(\Psi_{\mathrm{pd}}\right)$ and midday $\left(\Psi_{\mathrm{md}}\right)$ leaf water potential of control and kaolin-sprayed grapevine leaves in 2012 and 2013 . Values are presented as mean, $n=8$ per treatment. Statistical analysis was performed using a two-way factorial ANOVA. Different lowercase letters represent significant differences between the treatment (control vs. kaolin), in the same year, and * represents significant differences between years within the same treatment $(p<0.05)$.

\begin{tabular}{lllllll}
\hline & $\Psi_{\mathrm{pd}}[\mathrm{MPa}]$ & $\Psi_{\mathrm{md}}[\mathrm{MPa}]$ & $\Psi_{\mathrm{pd}}[\mathrm{MPa}]$ & $\Psi_{\mathrm{md}}[\mathrm{MPa}]$ & $\Psi_{\mathrm{pd}}[\mathrm{MPa}]$ & $\Psi_{\mathrm{md}}[\mathrm{MPa}]$ \\
\hline & July & & August & \multicolumn{3}{c}{ September } \\
2012 & & & & & \\
Control & -0.445 & -1.16 & -0.545 & -1.37 & -0.850 & -1.48 \\
Kaolin & -0.413 & -1.05 & -0.546 & -1.39 & -0.867 & -1.37 \\
2013 & & & & & & \\
Control & $-0.408^{\mathrm{a}}$ & $-1.23^{\mathrm{a}^{*}}$ & -0.550 & -1.41 & $-0.538^{*}$ & $-1.45^{\mathrm{a}}$ \\
Kaolin & $-0.242^{\mathrm{b}^{*}}$ & $-1.15^{\mathrm{b}}$ & -0.454 & -1.43 & $-0.467^{*}$ & $-1.19^{\mathrm{b}^{*}}$ \\
Two-way ANOVA $(p$-values) & & & & & & \\
Treatment & 0.003 & 0.047 & 0.180 & 0.353 & 0.610 & $<0.001$ \\
Year & 0.002 & 0.197 & 0.220 & 0.109 & $<0.001$ & $<0.001$ \\
Treatment $\times$ year & 0.087 & 0.197 & 0.173 & 0.901 & 0.412 & 0.005 \\
\hline
\end{tabular}


Table 2. Kaolin application effects on stomatal condutance $\left(g_{\mathrm{s}}, \mathrm{mmol} \mathrm{m}^{-2} \mathrm{~s}^{-1}\right)$, net $\mathrm{CO}_{2}$ assimilation $\left(P_{\mathrm{N}}, \mu \mathrm{mol} \mathrm{m} \mathrm{m}^{-2} \mathrm{~s}^{-1}\right)$, intrinsic wateruse efficiency $\left(P_{\mathrm{N}} / g_{\mathrm{s}}, \mu \mathrm{mol} \mathrm{mol}{ }^{-1}\right)$, intercellular $\mathrm{CO}_{2}$ concentration to ambient $\mathrm{CO}_{2}$ concentration ratio $\left(C_{\mathrm{i}} / C_{\mathrm{a}}\right)$, and transpiration rate $\left(E, \mathrm{mmol} \mathrm{m}^{-2} \mathrm{~s}^{-1}\right)$ in July (one week after kaolin application) and September (two months after kaolin application) 2012 and 2013. Values are presented as mean, $n=8$ per treatment. Statistical analysis was performed using a two-way factorial ANOVA. Different lowercase letters represent significant differences between the treatment (control vs. kaolin), in the same year, and * represents significant differences between years within the same treatment $(p<0.05)$.

\begin{tabular}{|c|c|c|c|c|c|c|c|c|c|c|}
\hline & $g_{\mathrm{s}}$ & $P_{\mathrm{N}}$ & $P_{\mathrm{N}} / \mathrm{g}_{\mathrm{s}}$ & $C_{\mathrm{i}} / C_{\mathrm{a}}$ & $E$ & $g_{\mathrm{s}}$ & $P_{\mathrm{N}}$ & $P_{\mathrm{N}} / \mathrm{g}_{\mathrm{s}}$ & $C_{\mathrm{i}} / C_{\mathrm{a}}$ & $E$ \\
\hline July 2012 & Morning & & & & & Midday & & & & \\
\hline Control & 199.7 & 7.43 & 57.8 & 0.688 & 3.79 & 99.8 & 5.92 & 60.8 & 0.659 & 3.16 \\
\hline Kaolin & 165.5 & 10.8 & 65.8 & 0.640 & 4.39 & 123.0 & 7.80 & 64.8 & 0.631 & 3.81 \\
\hline Significance & ns & ns & ns & ns & ns & ns & $*$ & ns & ns & ns \\
\hline September 2012 & Morning & & & & & Midday & & & & \\
\hline Control & $47.5^{\mathrm{a}}$ & $4.19^{\mathrm{a}}$ & 80.2 & 0.493 & 2.20 & $30.2^{\mathrm{a}}$ & $2.65^{\mathrm{a}}$ & 85.1 & 0.555 & $1.49^{\mathrm{a}}$ \\
\hline Kaolin & $93.6^{\mathrm{b}}$ & $7.85^{\mathrm{b}}$ & 88.5 & 0.543 & 2.73 & $45.9^{\mathrm{b}}$ & $3.98^{\mathrm{b}}$ & 87.1 & 0.544 & $2.02^{\mathrm{b}}$ \\
\hline \multicolumn{11}{|l|}{2013} \\
\hline Control & $67.8^{\mathrm{a}}$ & $3.96^{\mathrm{a}}$ & $57.4^{\mathrm{a}^{*}}$ & $0.675^{\mathrm{a}^{*}}$ & $3.46^{\mathrm{a}^{*}}$ & $35.9^{\mathrm{a}}$ & $1.87^{\mathrm{a}}$ & $46.6^{\mathrm{a}^{*}}$ & $0.755^{\mathrm{a}^{*}}$ & $1.12^{\mathrm{a}}$ \\
\hline Kaolin & $132^{b^{*}}$ & $9.14^{\mathrm{b}}$ & $71.7^{\mathrm{b}^{*}}$ & $0.588^{\mathrm{b}}$ & $5.42^{\mathrm{b}^{*}}$ & $69.7^{\mathrm{b}^{*}}$ & $6.58^{\mathrm{b}^{*}}$ & $96.4^{\mathrm{b}}$ & $0.515^{\mathrm{b}}$ & $2.27^{\mathrm{b}}$ \\
\hline \multicolumn{11}{|c|}{ Two-way ANOVA ( $p$-values) } \\
\hline Treatment & $<0.001$ & $<0.001$ & 0.039 & 0.533 & 0.010 & $<0.001$ & $<0.001$ & 0.027 & 0.016 & $<0.001$ \\
\hline Year & 0.035 & 0.552 & 0.001 & 0.001 & $<0.001$ & 0.003 & 0.119 & 0.193 & 0.088 & 0.738 \\
\hline Treatment $\times$ year & 0.494 & 0.398 & 0.565 & 0.028 & 0.117 & 0.05 & 0.007 & 0.039 & 0.025 & 0.086 \\
\hline
\end{tabular}

than by the treatment, mainly in July. The $\mathrm{q}_{\mathrm{N}}$ values were 22.5 and $58.0 \%$ higher in the kaolin-treated plants in 2012 and 2013, respectively, compared with those of the control during the midday period in September. Relating to ETR, the plants treated with kaolin had significantly higher values than the control ones. The $\mathrm{F}_{\mathrm{v}}{ }^{\prime} / \mathrm{F}_{\mathrm{m}}$ ' values in the plants treated with kaolin showed significant differences in September and the sprayed plants exhibited the higher values.

Foliar metabolic assays and oxidative stress indicators: No significant differences were found in photosynthetic pigment concentrations in July (Table 4). Conversely, kaolin particles caused a significant effect on the leaf pigment contents two months later (Table 4). In September, the $\mathrm{Chl}$ and Car concentrations were significantly higher in the kaolin-treated leaves. However, neither $\mathrm{Chl} a / b$ nor $\mathrm{Chl} / \mathrm{Car}$ ratio were affected by the particle pulverization. In July, all parameters seemed to be influenced by the year. However, in September, only the $\mathrm{Chl} / \mathrm{Car}$ ratio was affected.

\section{Discussion}

Vines sprayed with kaolin showed lower leaf temperature due to clay particles impact on leaf reflectance (Fig. 2S). According to Rosati et al. (2006), this effect reduces potentially damage caused by visible and ultraviolet radiations, and consequently reduces heat stress and sunburn damage. Our results are in agreement with those obtained for many tree species including apple, pomegranate, pecan, walnut, almond, grapefruit, pear, and citrus, where kaolin application reduced leaf and/or
Concerning foliar metabolites, only SS concentration was not significantly affected in July 2012 (Table 5). In this period, all other parameters were lower in the kaolintreated leaves. In the treated plants, almost all biochemical variables were affected by the year during this month. The SS and St concentrations were significantly enhanced in the treated leaves in September (Table 5). The SS contents increased approximately 19.5 and $13.1 \%$ in 2012 and 2013 , respectively, and the St concentration increased by approximately 46.5 and $6.3 \%$ in 2012 and 2013, respectively. The TP content, in this period, only showed significant differences between 2012 and 2013 and the SP content was higher in the kaolin-sprayed leaves. In this period, the amount of TP was lower.

Yield: The kaolin-treated plants showed higher values, with increases of 15.0 and $16.2 \%$ in 2012 and 2013, respectively (Fig. 3). In 2013, both treated and untreated plants boosted their production for more than the double, with significant differences.

canopy temperature by $1-6^{\circ} \mathrm{C}$ (Glenn et al. 2003, Rosati et al. 2006, Shellie and King 2013). Together, the kaolin effects caused, in this specific study on field-grown grapevines, a significant increment of $g_{\mathrm{s}}$ and $P_{\mathrm{N}}$, when compared with the untreated plants, mainly two months after the application. The lower values of $P_{\mathrm{N}}$ and $g_{\mathrm{s}}$ in the control plants at the morning and midday periods suggested that the decline in $P_{\mathrm{N}}$ could be related to stomatal limitations which are closely associated with 


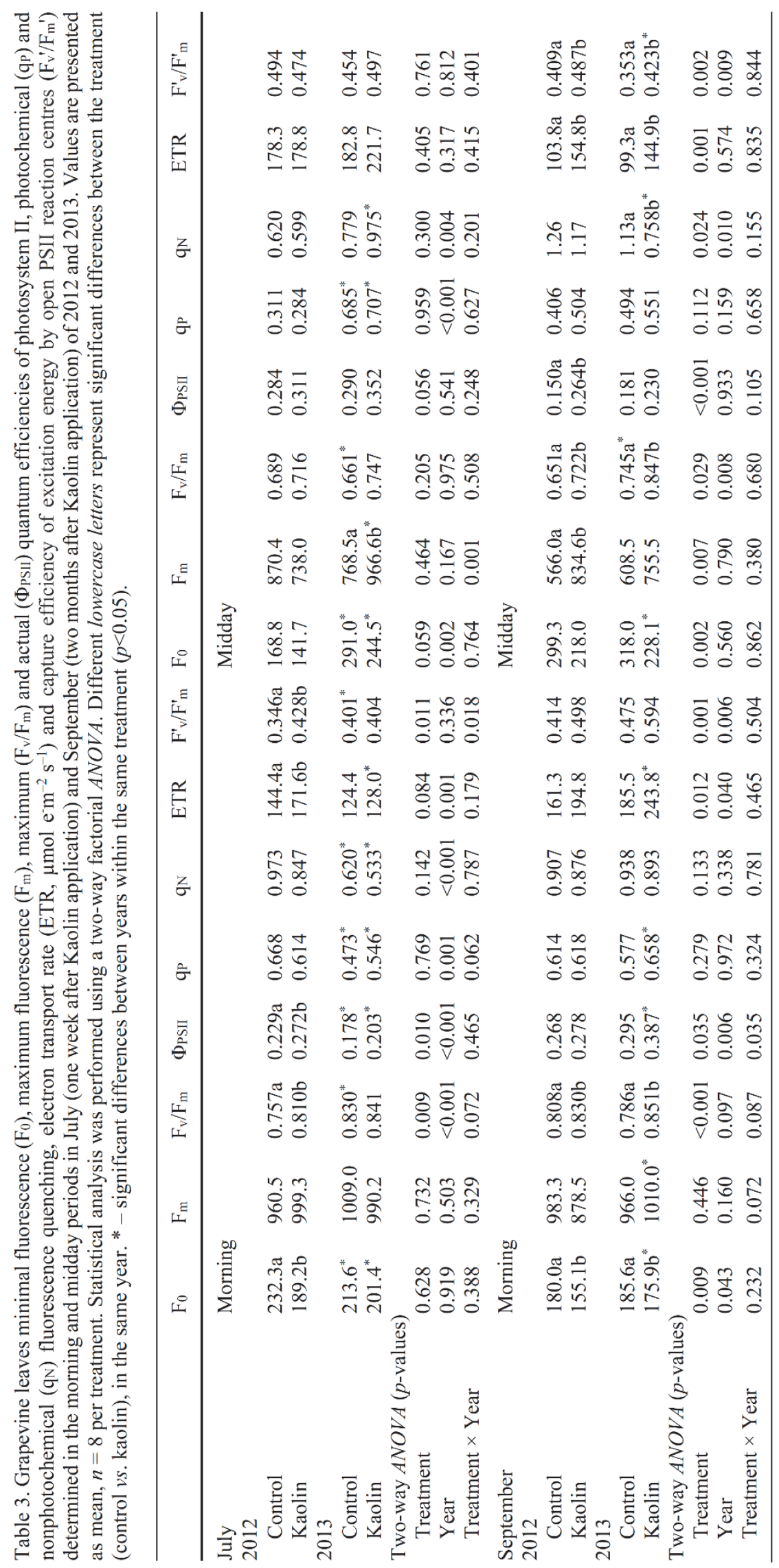


Table 4. Leaf photosynthetic pigments in control and kaolin-sprayed grapevine in July (kaolin application) and September 2012 and 2013. Values are presented as mean $(n=6$ per treatment). Statistical analysis was performed using a two-way factorial ANOVA. Different lowercase letters represent significant differences between the treatment (control vs. kaolin), in the same year, and $*$ represents significant differences between years within the same treatment $(p<0.05)$. Chl - chlorophyll; Car - carotenoids.

\begin{tabular}{lllll}
\hline & Chl $a / b$ & $\begin{array}{l}\mathrm{Chl}(a+b) \\
{\left[\mathrm{mg} \mathrm{g}^{-1}(\mathrm{DM})\right]}\end{array}$ & $\begin{array}{l}\text { Car } \\
{\left[\mathrm{mg} \mathrm{g}^{-1}(\mathrm{DM})\right]}\end{array}$ & Chl/Car \\
\hline July 2012 & & & & \\
Control & 2.68 & 5.08 & 1.11 & 4.59 \\
Kaolin & 2.55 & 4.63 & 1.02 & 4.60 \\
2013 & & & & \\
Control & $3.13^{*}$ & $3.60^{*}$ & $0.936^{*}$ & $3.84^{*}$ \\
Kaolin & $3.03^{*}$ & $3.45^{*}$ & 0.914 & $3.77^{*}$ \\
Two-way ANOVA (p-values) & & & & \\
Treatment & 0.049 & 0.138 & 0.275 & 0.827 \\
Year & $<0.001$ & $<0.001$ & 0.009 & $<0.001$ \\
Treatment $\times$ year & 0.870 & 0.436 & 0.512 & 0.773 \\
September & & & & \\
2012 & & & & 4.35 \\
Control & 2.36 & $3.37^{\mathrm{a}}$ & $0.774 \mathrm{a}$ & 4.95 \\
Kaolin & 2.37 & $4.65 \mathrm{~b}$ & $0.894 \mathrm{~b}$ & \\
2013 & & & & 3.82 \\
Control & 2.70 & $2.93 \mathrm{a}$ & $0.761^{\mathrm{a}}$ & $3.93^{*}$ \\
Kaolin & 2.73 & $3.81^{\mathrm{b}}$ & $0.910^{\mathrm{b}}$ & \\
Two-way ANOVA $(p$-values) & & & & 0.242 \\
Treatment & 0.897 & 0.011 & 0.049 & 0.016 \\
Year & 0.039 & 0.114 & 0.977 & 0.416 \\
Treatment $\times$ year & 0.948 & 0.606 & 0.822 & \\
\hline & & & &
\end{tabular}

lower leaf water potential (Table 1). The regulation of stomatal aperture limits the $\mathrm{CO}_{2}$ entry into leaves and consequently leads to a decrease of $P_{\mathrm{N}}$ as a result of the reduced $\mathrm{CO}_{2}$ availability (Centritto et al. 2005). In addition, the $E$ was also lower in the control plants, which is in close association with the variation in $g_{\mathrm{s}}$, as reported by Poni et al. (2009). Moreover, as the stress progressed, the nonstomatal component of photosynthesis was also affected, as demonstrated by the decrease of $P_{\mathrm{N}}$ and $g_{\mathrm{s}}$ which was associated with the increase of $C_{\mathrm{i}} / C_{\mathrm{a}}$ ratio and the decrease of $P_{\mathrm{N}} / g_{\mathrm{s}}$ during the midday period in 2013 (Table 2). The higher $C_{\mathrm{i}} / C_{\mathrm{a}}$ and lower $P_{\mathrm{N}} / g_{\mathrm{s}}$ in the control plants occurred due to nonstomatal limitations, either through $\mathrm{CO}_{2}$ diffusion, carboxylation efficiency (Medrano et al. 2002), and/or photochemical perturbations. This last aspect was confirmed by $\mathrm{Chl} a$ fluorescence analysis. In general, total electron flow through PSII was more inhibited in the control plants, as indicated by reductions in the $\mathrm{F}_{\mathrm{v}} / \mathrm{F}_{\mathrm{m}}, \Phi_{\mathrm{PSIl}}, \mathrm{F}_{\mathrm{v}}{ }^{\prime} / \mathrm{F}_{\mathrm{m}}$ ', and ETR (Table 3), mainly in the September 2013. The sharp increase in $\mathrm{F}_{0}$ associated with a decrease in $F_{v} / F_{m}$, as observed in the control plants, means that the photoprotective capacity of the leaves was exceeded and photoinhibitory damage in the PSII had occurred (Valladares and Pearcy 1997). This process was also observed in plant response to high temperature (Gamon and Pearcy 1989) and water stress (Epron et al. 1992) (Table 3).
Contrary to the control plants, a noticeably lower decrease was found in $g_{\mathrm{s}}, P_{\mathrm{N}}$, and PSII photochemistry from morning to midday period in the kaolin-treated plants (Jifon and Syvertsen 2003). These results together, with the increase in $\mathrm{q}_{\mathrm{N}}$ (for control plants), mainly at midday period in September, suggested a limited regulation for electron transport that was enough to match the decreased demand for electrons through $\mathrm{NADP}^{+}$consumption (DaMatta et al. 2002), which means a reduction in the opening of reaction centres (reduced quinones). The high value of $\mathrm{q}_{\mathrm{N}}$ means a high dissipation of the excess energy by heat, avoiding the photosystem damages by oxidation (Baker 2008).

The $\mathrm{RI}_{\text {red edge, evaluated through leaf reflectance, is }}$ used for Chl prediction, and follows similar trends to those indicated in a study with apple (Merzlyak et al. 2003). As mentioned above, two months after the kaolin treatment, the $\mathrm{RI}_{\text {red edge }}$ was higher in the treated leaves (Fig. 1) and during the same period, kaolin-treated plants had also higher Chl $(a+b)$ contents (Table 4$)$. The lower Chl $(a+b)$ concentration in the control plants revealed a sign of oxidative stress due to Chl degradation and/or reduced Chl synthesis (Smirnoff 1993). Also, the kaolin-treated leaves showed the higher Car content, which has an important role in preventing $\mathrm{Chl}$ degradation. Thus, the relationship between Chl and Car may be used as a potential indicator of photooxidative damage (Moutinho-Pereira et al. 2007). 
Table 5. Grapevine leaves concentration of soluble sugars (SS), starch (St), total phenols (TP), soluble proteins (SP), and total thiobarbituric acid-reactive substances concentration (TBARS) quantified in September 2012 and 2013 after application of kaolin in July. Values are presented as mean $(n=6$ per treatment). Statistical analysis was performed using a two-way factorial ANOVA. Different lowercase letters represent significant differences between the treatment (control vs. kaolin), in the same year, and * represents significant differences between years within the same treatment $(p<0.05)$.

\begin{tabular}{|c|c|c|c|c|c|}
\hline & $\begin{array}{l}\mathrm{SS} \\
{\left[\mathrm{mg} \mathrm{g}^{-1}(\mathrm{DM})\right]}\end{array}$ & $\begin{array}{l}\mathrm{St} \\
{\left[\mathrm{mg} \mathrm{g}^{-1}(\mathrm{DM})\right]}\end{array}$ & $\begin{array}{l}\text { TP } \\
{\left[\mathrm{mg} \mathrm{g}^{-1}(\mathrm{DM})\right]}\end{array}$ & $\begin{array}{l}\text { SP } \\
{\left[\mathrm{mg} \mathrm{g}^{-1}(\mathrm{DM})\right]}\end{array}$ & $\begin{array}{l}\text { TBARS } \\
{\left[\mu \mathrm{mol} \mathrm{g}{ }^{-1}(\mathrm{DM})\right]}\end{array}$ \\
\hline \multicolumn{6}{|l|}{ July 2012} \\
\hline Control & 110.7 & $19.7^{\mathrm{a}}$ & $316.0^{\mathrm{a}}$ & $79.2^{\mathrm{a}}$ & $10.8^{\mathrm{a}}$ \\
\hline Kaolin & 117.8 & $10.3^{b}$ & $236.8^{\mathrm{b}}$ & $64.8^{\mathrm{b}}$ & $8.55^{\mathrm{b}}$ \\
\hline \multicolumn{6}{|l|}{2013} \\
\hline Control & $183.5^{*}$ & 20.9 & 308.2 & $69.5^{*}$ & $6.10^{*}$ \\
\hline Kaolin & $197.9^{*}$ & $19.0^{*}$ & $301.9^{*}$ & $71.2^{*}$ & 5.98 \\
\hline \multicolumn{6}{|c|}{ Two-way ANOVA ( $p$-values) } \\
\hline Treatment & 0.228 & 0.046 & 0.012 & 0.031 & 0.536 \\
\hline Year & $<0.001$ & 0.010 & 0.078 & $<0.001$ & 0.043 \\
\hline Treatment $\times$ year & 0.679 & 0.004 & 0.029 & $<0.001$ & 0.491 \\
\hline \multicolumn{6}{|l|}{ September 2012} \\
\hline Control & 145.4 & $42.3^{\mathrm{a}}$ & 268.0 & 103.0 & 4.96 \\
\hline Kaolin & 180.7 & $79.0^{\mathrm{b}}$ & 285.2 & 146.3 & 4.73 \\
\hline \multicolumn{6}{|l|}{2013} \\
\hline Control & $197.5^{\mathrm{a}^{*}}$ & $16.4^{*}$ & $364.7^{\mathrm{a}^{*}}$ & $128.0^{\mathrm{a}^{*}}$ & $5.93^{\mathrm{a}}$ \\
\hline Kaolin & $227.3^{b^{*}}$ & $17.5^{*}$ & $292.8^{\mathrm{b}^{*}}$ & $204.8^{\mathrm{b}^{*}}$ & $5.13^{\mathrm{b}}$ \\
\hline \multicolumn{6}{|c|}{ Two-way ANOVA ( $p$-values) } \\
\hline Treatment & 0.020 & $<0.001$ & 0.119 & 0.049 & 0.041 \\
\hline Year & 0.001 & $<0.001$ & $<0.001$ & $<0.001$ & 0.283 \\
\hline Treatment $\times$ year & 0.832 & $<0.001$ & 0.049 & 0.461 & 0.648 \\
\hline
\end{tabular}

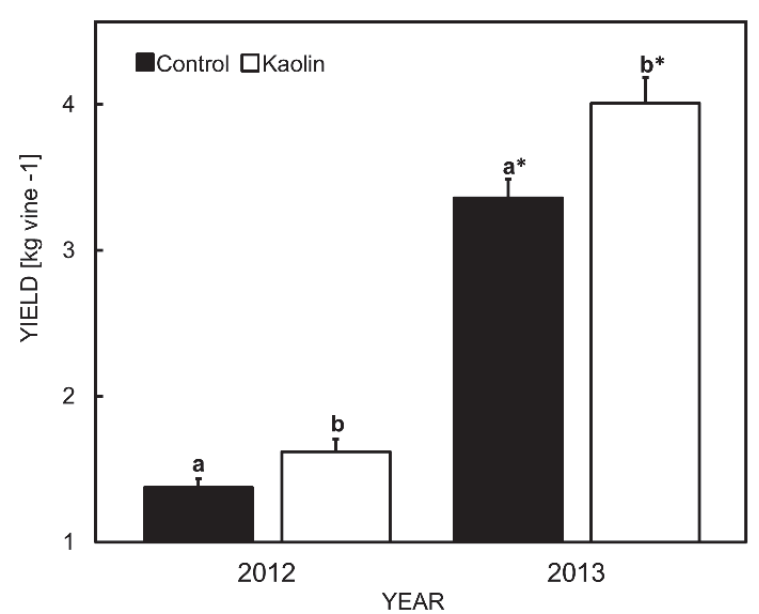

Fig. 3. Yield of kaolin-sprayed vines and control ones. Values are presented as mean \pm standard deviation (SD), $n=60$ plants per treatment. Statistical analysis was performed using a two-way factorial ANOVA. Different lowercase letters represent significant differences between the treatment (control vs. kaolin), in the same year, and * represents significant differences between years within the same treatment $(p<0.05)$.

Another indicator of oxidative stress in the control leaves was observed in September 2013 due to the increase in lipid peroxidation (Table 5). It was extensively described that reactive oxygen species cause lipid peroxiETRdation leading to membrane damage (Shalata and Tal 1998). Our results suggested that kaolin application reduced the oxidative damage of cell membranes which was indicated by the decrease in lipid peroxidation. In this context, the control plants needed to develop some defense mechanisms against oxidative stress, such as the increase in TP concentration (Bacelar et al. 2006). This increase in total polyphenols could be a consequence of phenylalanine ammonia lyase activated under high temperature (Fig. 2) (Wen et al. 2008). According to the growth/differentiation balance theory (Koricheva et al. 1998), the pathways which compete for phenylalanine as a precursor, can lead either to phenylpropanoid or to protein synthesis. Under stress conditions, carbon is diverted to phenylpropanoid synthesis, which might explain the increase of phenolic compound contents in the control plants. However, under adequate water availability and light conditions, the growth and development are priority and the bulk of phenylalanine is used for protein synthesis (Koricheva and Larsson 1998), which seems to be occurring in the kaolintreated leaves in September (Table 5). Changes in soluble proteins are important indicators to understand the impact of stress on cell proteolysis and protein synthesis (Santos and Caldeira 1999). The lower values of SP in the control plants (Table 5) might be a consequence of the hydrolysis of some proteins in response to an increased request for amino acids induced by higher leaf temperature under water stress (Yadav et al. 1999). One of the most important responses of plants to water stress is an overproduction of 
diverse types of compatible solutes (Ashraf and Harris 2004). It has been already demonstrated by our group that kaolin-treated plants showed lower contents of proline (Dinis et al. 2016), which reinforces the idea that this particle film is a protecting agent for grapevines growing under water stress, strong light, and high temperature conditions.

The kaolin-treated plants had higher $P_{\mathrm{N}}$, sink capacity, and consequently the yield per vine, which led to a higher SS concentration than that of the control plants (Table 5). Thus, with lower photosynthetic limitations in the kaolintreated plants, SS values increased, leading to a temporary increase in the St concentration (Table 5). Overall, taken together these results can explain the higher yield per plant in grapevines treated with kaolin. Meanwhile, more rain in April/May 2012, coinciding with the flowering and fruitset stage, explained the decrease in the production per vine,

\section{References}

Ashraf M., Harris P.J.C.: Potential biochemical indicators of salinity tolerance in plants. - Plant Sci. 166: 3-16, 2004.

Bacelar E.A., Santos D.L., Moutinho-Pereira J.M. et al.: Immediate responses and adaptative strategies of three olive cultivars under contrasting water availability regimes: Changes on structure and chemical composition of foliage and oxidative damage. - Plant Sci. 170: 596-605, 2006.

Baker N.R.: Chlorophyll fluorescence: a probe of photosynthesis in vivo. - Annu. Rev. Plant Biol. 59: 89-113, 2008.

Bilger W., Schreiber U.: Energy-dependent quenching of darklevel chlorophyll fluorescence in intact leaves. - Photosynth. Res. 10: 303-308, 1986.

Bradford M.M.: A rapid and sensitive method for the quantification of microgram quantities of protein utilizing the principle of protein-dye binding. - Anal. Biochem. 72: 248-254, 1976.

Centritto M., Wahbi S., Serraj R., Chaves M.M.: Effects of partial root-zone (PRD) on adult olive tree (Olea europaea) in field conditions under arid climate. II. Photosynthetic responses. Agr. Ecosyst. Environ. 106: 303-311, 2005.

Chaves M.M., Santos T., Souza C.R. et al.: Deficit irrigation in grapevine improves water-use efficiency while controlling vigour and production quality. - Ann. Appl. Biol. 150: 237252, 2007.

Costa H., Gallego, S.M., Tomaro, M.L.: Effect of UV-B radiation on antioxidant defense system in sunflower cotyledons. - Plant Sci. 162: 939-945, 2002.

DaMatta F.M., Loos R.A., Silva E.A., Loureiro M.E.: Limitations to photosynthesis in Coffea canephora as a result of nitrogen and water availability. - J. Plant Physiol. 159: 975981, 2002.

Dinis L.-T., Correia C.M., Ferreira H.F., Gonçalves B. et al.: Physiological and biochemical responses of Semillon and Muscat Blanc à Petits Grains winegrapes grown under Mediterranean climate. - Sci. Hortic.-Amsterdam 175: 128138, 2014.

Dinis L.-T., Ferreira H., Pinto G. et al.: Kaolin-based, foliar reflective film protects photosystem II structure and function in grapevine leaves exposed to heat and high solar radiation. Photosynthetica 54: 47-55, $2016 \mathrm{a}$.

Dinis L.-T., Bernardo S., Conde A. et al.: Kaolin exogenous relatively to the 2013 season.

In summary, this study showed that kaolin foliar spray reduced leaf temperature and increased leaf water potential, $g_{\mathrm{s}}$, and $P_{\mathrm{N}}$ (improving overall plant physiological performance). The increase of photosynthesis, soluble proteins, soluble sugars, and starch, and the reduction of solar damage, make the application of Surround $\mathbb{\circledR}$ (kaolin) a promising short-term climate change mitigation strategy. Its effectiveness in reducing summer stress on grapevines and improving their yield quality reinforced experimental data published earlier (Dinis et al. 2016), but also added new information. Kaolin can be efficiently used to alleviate the negative impacts of summer stress in the Mediterranean-like climates, especially taking into account the climate change projections for these regions. Moreover, kaolin is a natural product, which can be used in organic production.

application boosts antioxidant capacity and phenolic content in berries and leaves of grapevine under summer stress. - J. Plant Physiol. 191: 45-53, 2016b.

dos Santos T.P., Lopes C.M., Rodrigues M.L. et al.: Effects of deficit irrigation strategies on cluster microclimate for improving fruit composition of Moscatel field-grown grapevines. - Sci. Hortic.-Amsterdam 112: 321-330, 2007.

Epron D., Dreyer E. Bréda N.: Photosynthesis of oak trees (Quercus petraea (Matt) Liebl.) during drought stress under field conditions: diurnal course of net $\mathrm{CO}_{2}$ assimilation and photochemical efficiency of photosystem II. - Plant Cell Environ. 15: 809-820, 1992.

FAO: World Reference Base for Soil Resources 2014, update 2015. International Soil Classification System for Naming Soils and Creating Legends for Soil Maps. World Soil Resources Reports No. 106. FAO, Rome 2015.

Ferrandino A., Lovisolo C.: Abiotic stress effects on grapevine (Vitis vinifera L.): Focus on abscisic acid-mediated consequences on secondary metabolism and berry quality. Environ. Exp. Bot. 103: 138-147, 2014.

Fraga H., Malheiro A.C., Moutinho-Pereira J., Santos J.A.: Future scenarios for viticultural zoning in Europe: ensemble projections and uncertainties. - Int. J. Biometeorol. 57: 909925, 2013.

Fraga H., Malheiro A.C., Moutinho-Pereira J. et al.: Very high resolution bioclimatic zoning of Portuguese wine regions: present and future scenarios. - Reg. Environ. Change 14: 295306, 2014a.

Fraga H., Malheiro A.C., Moutinho-Pereira J., Santos J.A.: Climate factors driving wine production in the Portuguese Minho region. - Agr. Forest Meteorol. 185: 26-36, 2014b.

Fraga H., de Cortázar Atauri I.G., Malheiro A.C, Santos J.A.: Modelling climate change impacts on viticultural yield, phenology and stress conditions in Europe. - Glob. Change Biol. 22: 3774-3788, 2016.

Gamon J.A., Pearcy R.W.: Leaf movement, stress avoidance and photosynthesis in Vitis californica. - Oecologia 79: 475-481, 1989.

Genty B., Briantais J.M., Baker N.R.: The relationship between the quantum yield of photosynthetic electron transport and 
quenching of chlorophyll fluorescence. - Biochim. Biophys. Acta. 990: 87-92, 1989.

Gitelson A.A., Merzlyak M.N.: Non-destructive assessment of chlorophyll, carotenoid and anthocyanin content in higher plant leaves: Principles and algorithms - In: Stamatiadis S., Lynch J.M., Shepers J.S. (ed.): Non-destructive Assessment of Chlorophyll, Carotenoids and Anthocyanin Content in Higher Plant Leaves: Principles and Algo-rithms. Remote Sensing for Agriculture and the Environment. Pp. 78-94. Ella, Greece 2004.

Glenn D.M., Erez A., Puterka G.J., Gundrum P.: Particle films affect carbon assimilation and yield in 'Empire' apple. - J. Am. Soc. Hortic. Sci. 128: 356-362, 2003.

Glenn D.M., Puterka G.J.: Particle films: A new technology for agriculture. - In: Janick J. (ed.): Horticultural Reviews, Vol. 31. Pp. 1-44, John Wiley \& Sons, New Jersey 2005.

Glenn D.M., Puterka G.J., Drake S.R. et al.: Particle film application influences apple leaf physiology fruit yield and fruit quality. - J. Am. Soc. Hortic. Sci. 126: 175-181, 2001.

Hannah L., Roehrdanz P.R., Ikegami M. et al.: Climate change, wine, and conservation. - P. Natl. Acad. Sci. USA 110: 69076912, 2013.

Heath R.L., Packer L.: Photoperoxidation in isolated chloroplasts. I Kinetics and stoichiometry of fatty acid peroxidation. - Arch. Biochem. Biophys. 125: 189-198, 1968.

Iacono F., Buccella A., Peterlunger E.: Water stress and rootstock influence on leaf gas exchange of grafted and ungrafted grapevines. - Sci. Hortic.-Amsterdam 75: 27-39, 1998.

IPCC.: Climate Change. The Physical Science Basis. Summary for Policymakers. Working Group I Contribution to the IPCC Fifth Assessment Report. Pp. 1-28. Cambridge Univ. Press, Cambridge 2013.

Irigoyen J.J., Einerich D.W., Sánchez-Diáz M.: Water stress induced changes in concentrations of proline and total soluble sugars in nodulated alfalfa (Medicago sativa) plants. - Plant Physiol. 84: 55-60, 1992.

Jifon J.L., Syvertsen J.P.: Kaolin particle film applications can increase photosynthesis and water use efficiency of 'Ruby Red' grapefruits leaves. - J. Am. Soc. Hortic. Sci. 128: 107-112, 2003.

Jones G.V., White M.A., Cooper O.R., Storchmann K.: Climate change and global wine quality. - Climatic Change 73: 319343,2005 .

Koricheva J., Larsson S., Haukioja E., Keinänen M.: Regulation of woody plant secondary metabolism by resource availability: hypothesis testing by means of meta-analysis. - Oikos 83: 212226, 1998.

Kottek M., Grieser J., Beck C.: World Map of the Köppen-Geiger climate classification updated. - Meteorol Z. 15: 259-263, 2006.

Lichtenthaler H.K.: Chlorophylls and carotenoids: pigments of photosynthetic biomembranes. - Methods Enzymol. 148: 350$382,1987$.

Marinari S., Calfapietra C., De Angelis P. et al.: Impact of elevated $\mathrm{CO}_{2}$ and nitrogen fertilization on foliar elemental composition in a short rotation poplar plantation. - Environ. Pollut. 147: 507-515, 2007.

Medrano H., Escalona J.M., Bota J. et al.: Regulation of photosynthesis of $\mathrm{C} 3$ plants in response to progressive drought: Stomatal conductance as a reference parameter. - Ann. Bot.London 89: 895-905, 2002.

Merzlyak M.N., Solovchenko A.E., Gitelson A.A.: Reflectance spectral features and non-destructive estimation of chlorophyll, carotenoid and anthocyanin content in apple fruit. - Postharvest
Biol. Tec. 27: 197-211, 2003.

Moutinho-Pereira J., Correia C.M., Gonçalves B. et al.: Impacts of leafroll associated viruses (GLRaV-1 and -3) on the physiology of the Portuguese grapevine cultivar 'Touriga Nacional' growing under field conditions. - Ann. Appl. Biol. 160: 237-249, 2012.

Moutinho-Pereira J.M., Correia C.M., Gonçalves B. et al.: Leaf gas-exchange and water relations of grapevines grown in three different conditions. - Photosynthetica 42: 81-86, 2004.

Moutinho-Pereira J.M., Magalhães N., Gonçalves B.: Gas exchange and water relations of three Vitis vinifera L. cultivars growing under Mediterranean climate. - Photosynthetica 45: 202-207, 2007

Osaki M., Shinano T., Tadano T.: Redistribution of carbon and nitrogen compound from the shoot to the harvesting organs during maturation in field crops. - Soil Sci. Plant Nutr. 37: 117128, 1991.

Patakas A., Noitsakis B.: Leaf age effects on solute accumulation in water-stressed grapevines. - J. Plant Physiol. 158: 63-69, 2001.

Poni S., Bernizzoni F., Civardi S.: Performance and water-use efficiency (single-leaf vs. whole-canopy) of well-watered and half-stressed split-root Lambrusco grapevines grown in Po Valley (Italy). - Agr. Ecosyst. Environ. 129: 97-106, 2009.

Rosati A., Metcalf S.G., Buchner R.P. et al.: Physiological effects of kaolin applications in well-irrigated and waterstressed walnut and almond trees. - Ann. Bot.-London 98: 267275, 2006.

Sampol B., Bota J., Riera D. et al.: Analysis of the virus-induced inhibition of photosynthesis in malmsey grapevines. - New Phytol. 160: 403-412, 2003.

Santos C.V., Caldeira G.: Comparative responses of Helianthus annuus plants and calli exposed to $\mathrm{NaCl}$. I. Growth rate and osmotic adjustment in intact plants and calli. - J. Plant Physiol. 155: 769-777, 1999.

Šesták Z., Čatský J., Jarvis P.G.: Plant Photosynthetic Production. Manual of Methods. Pp. 818. Dr. W. Junk Publ., Haia 1971.

Shalata A., Tal A.: The effects of salt stress on lipid peroxidation and antioxidants in the leaf of the cultivated tomato and its wild salt-tolerant relative Lycopersicon pennellii. - Physiol. Plantarum 104: 169-174, 1998.

Shellie K.C., King B.A.: Kaolin particle film and water deficit influence malbec leaf and berry temperature, pigments, and photosynthesis. - Am. J. Enol. Viticult. 64: 223-230, 2013.

Singleton V.L., Rossi J.A.J.: Colorimetry of total phenolics with phosphomolybdic-phosphotungstic acid reagents. - Am. J. Enol. Viticult. 16: 144-158, 1965.

Smirnoff N.: The role of active oxygen in the response of plants to water deficit and desiccation. - New Phytol. 125: 27-58, 1993.

Valladares R., Pearcy R.W.: Interaction between water stress, sun-shade acclimation, heat tolerance and photoinhibition in the sclerophyll Heteromeles arbutifolia. - Plant Cell Environ. 20: 25-36, 1997.

von Caemmerer S., Farquhar G.D.: Some relationships between the biochemistry of photosynthesis and the gas exchange of leaves. - Planta 153: 376-387, 1981.

Wen P.-F., Chen J.-Y., Wan S.-B. et al.: Salicylic acid activates phenylalanine ammonia-lyase in grape berry in response to high temperature stress. - Plant Growth Regul. 55: 1-10, 2008.

Yadav V.K., Gupta V., Neelam Y.: Hormonal regulation of nitrate in gram (Cicer arietinum) genotypes under drought. Indian J. Agr. Sci. 69: 592-595, 1999. 